\title{
An Approach to Evaluating the Quality of Websites Based on the Weighted Sum Preferred Levels of Performances Method
}

\author{
Darjan Karabasevic ${ }^{1}$, Dragisa Stanujkic ${ }^{2}$, Mladjan \\ Maksimovic $^{3}$, Gabrijela Popovic ${ }^{4}$, Oliver Momcilovic ${ }^{5}$
}

${ }^{1,3}$ Faculty of Applied Management, Economics and Finance, University Business Academy in Novi Sad, Jevrejska 24, Belgrade, Serbia, E-mail: darjan.karabasevic@mef.edu.rs; mladjan.maksimovic@mef.edu.rs

${ }^{2}$ Technical Faculty in Bor, University of Belgrade, Vojske Jugoslavije 12, 19210 Bor, Serbia, E-mail: dstanujkic@ @tbor.bg.ac.rs

${ }^{4}$ Faculty of Management in Zajecar, Megatrend University Belgrade, Park šuma “Kraljevica” bb, 19000 Zaječar, Serbia, E-mail: gabrijela.popovic@fmz.edu.rs

5 Faculty of Information Technology and Engineering, University „Union Nikola Tesla“, Jurija Gagarina 149a (TC Piramida), Staro sajmište 29, 11070 Belgrade, Serbia, E-mail: oliver.momcilovic@ fiti.edu.rs

Abstract: Measuring the quality of a website is important for companies in order to maintain their competitiveness. This manuscript intends to present a new multiple criteria decision-making approach devoted to the evaluation of the quality of websites from the viewpoint of their visitors. The proposed approach uses gaps between expectations and perceptions similar to the well-known SERVQUAL methodology. The proposed approach is also based on the use of the Weighted Sum Preferred Levels of Performances (WS PLP) approach and the proven smaller set of criteria, which enables the forming of less complex questionnaires, and as such, it should enable us to more easily collect the real attitudes of surveyed website visitors. The usability and efficiency of the proposed approach are considered in the case study devoted to the evaluation of the websites of three telecommunication companies in Serbia.

Keywords: MCDM; WS PLP approach; Company website; Website quality evaluation

\section{Introduction}

The emergence of new technologies, such as the Internet, has caused change in the manner companies do their business. In the last decades, the Internet has undoubtedly become the fastest-growing communications medium; accordingly, 
many companies have adopted and have been taking the advantages the Internet offers. The Internet has allowed companies of any size to be easily accessible in the cyberspace, in accordance with which small and large size companies are able to create websites in order to present their respective corporate missions, products or services to the world [1]. So, modern companies perform the largest portion of their communications with their customers over the Internet, usually in order to promote their own products and services. Therefore, Cebi [2] emphasizes the fact that the Internet is an effective tool for companies to reach their customers via their own websites.

Similarly to any commercial, the website helps companies to inform, persuade and remind their customers about and of, respectively, the company and its products and services. In his study, Ibrahim [3] has confirmed the fact that websites are the main bearers of the marketing activities of a company, which are actively used today. However, bearing in mind the fact that there is increasing competition, the quality of companies' websites is of great importance and, undoubtedly, it is critical for a company's achieving of goals [4]. For that reason, the quality of the website has become an important tool for the acquisition of new customers, as has been confirmed in numerous studies, only to name some of them: Stanujkic et al. [5], Al-Manasra et al. [6], Bai et al. [7], Lin [8], Kim and Stoel [9] and so on.

Therefore, measuring the quality of a website is important for companies in order to maintain their competitiveness. The SERVQUAL model, proposed by Parasuraman et al. [10], was often used for measuring a service quality. Somewhat later, based on SERVQUAL, other models for the evaluation of a service quality have been proposed, amongst which: WebQual [11; 12], E-S-QUAL, E-RecSQUAL [13] and so forth. Measuring the quality of a website mainly based on the WebQual has been the subject matter of numerous studies conducted by numerous researchers, such as: Loiacono et al. [14], Barnes and Vidgen [15-16], Shchiglik and Barnes [17], Park et al. [18], Park and Baek [19] and so on.

Quality is an attribute of a service that gives an insight how well it fulfils the customers' needs. Evaluating the service, in this case the website, quality is very complex and acquiring task. According to the previous mentioned models proposed for solving such a problem, different evaluation dimensions are emphasized which additionally complicates already complicated and complex issue. Different lists of evaluation criteria are proposed which often are not mutually compatible. If decision maker (hereinafter marked as DM) gives the priority to the certain set of evaluation criteria, neglecting the others, the decision would not be representative because it would not be based on the whole group of the involved criteria. In order to overcome the problems in decision-making process related to the appreciating of all evaluation criteria the Multiple Criteria Decision Making (MCDM) methods are introduced.

MCDM is one of the significant branches of operational research and it deals with problems which we are faced with when deciding in the presence of a large 
number of, usually conflicting, criteria. Therefore, Keeney and Raiffa [20] suggest the five key principles that should be considered when formulating criteria: completeness, the operational ability, decomposability, non-redundancy and the minimum size. It is stated by Beynon [21] that the DM's ability to make preference judgments about a number of different decision alternatives is the basis for making a decision. Further, Korhonen [22] points out the fact that the solving of a multi-criteria decision-making problem requires that the DM should make choice of the "reasonable" alternative out of a set of available alternatives the most consistent with his/her preferences. Until today, many different MCDM methods are proposed as well as its appropriate extensions that enable DM to incorporate the vagueness and uncertainty into the decision-making process [2326].

In this manuscript the WS PLP method [27] is proposed as a convenient tool that could be used for the website quality evaluation from two aspects, i.e. customers and companies. Customers could apply the WS PLP method in the process of the evaluation and selection of the websites of different kind. By applying the aforementioned method, companies could investigate how consumers evaluate their websites and what is their position related to their main competitors. The main goal is dichotomous: (1) first is to facilitate the decision-making process and enable DM (in this case customer) to choose website in accordance with his/her needs and requirements; (2) second is to enable companies to, by using the same tool on the group of examinees, estimate the quality of theirs websites, their rang according to competitors and to define what dimensions should be improved.

For the need of this paper, the evaluation process is performed by using the set of the evaluation criteria retrieved from the Webby Awards (http://webbyawards.com/judging-criteria/). The website's quality of the three telecommunication companies that operate in the Republic of Serbia are assessed by DMs involved in the process of the evaluation because of obtaining the more reliable results as possible. In order to show the possibilities of the proposed method, the manuscript is structured in the following manner: Section 2 presents Literature Review and Section 3 demonstrates the WS PLP approach. In Section 4 , the framework for evaluating the website quality is presented and a case study is given in Section 5. Ultimately, the conclusions are given at the end of the manuscript.

\section{Literature Review}

Website quality is topic that occupies the scientific attention because it has a significant impact on the business results and success of an organization. For example, Bai et al. [7] examined how the website quality have influence on the consumer satisfaction and willingness to shop online, and Jones and Kim [28] 
explore does website quality have impact on the young female consumers in the US to buy clothes online. The appropriate websites also could contribute to the hotel business by developing good relationships with their clients [29]. Certain attributes are very important when the website quality is in question because they contribute to the consumer satisfaction in a greater degree [30]. The consumer satisfaction is crucial dimension that is connected with website quality and question that arises is how to measure the quality of webiste as well as the consumer satisfaction that is connected to it?

Websites and its applications represent a kind of service and the tool proposed for the measuring the service quality is SERVQUAL, as previously stated. According to Parasuraman et al. [10] service quality is defined as a gap between consumer expectations and consumers' perceptions and five dimensions crucial for the measuring of service quality are identified and they are: tangibility, reliability, responsiveness, assurance and empathy. Further, the new appropriate models for the estimating of website quality was proposed such as: WebQual model [11-12], Web Quality (WQM) model [31] and WebQual TM quality evaluation model [14]. In various cases, when certain type of websites are evaluated that fullfils concrete customer need, different model is used. The mentioned models are very convinient for applying by practitioners who want to identify what performance of their website is good as those that need improvement so they could be in accordance with customer desire. But, on other hand there are consumers who also wants to choose the website according to their needs, but the use of mentioned models is not quite appropriate for them. Also, there is a need for the simpler questioners that companies could use for the investigating the opinions of their customers. In that case, the MCDM methods seems like appropriate solution that could help in resolving the mentioned issues.

In the past decades, the rapid development of operational research has caused the creation of many MCDM methods, such as: the Weighted Sum (WS) method [3233], the ELECTRE method [34], the AHP method [35-36], the TOPSIS method [37], the PROMETHEE method [38], the COPRAS method [39], and the VIKOR method [40]. Recently, the new generation of the MCDM methods is proposed such as: the MUSA method [41], the MULTIMOORA method [42], the ARAS method [43], the SWARA method [44], the FARE method [45], the WASPAS method [46], the KEMIRA method [47] and the EDAS method [48].

In a number of studies, MCDM methods have been successfully used for the purpose of the evaluation of the quality of websites. Burmaoglu and Kazancoglu [49] have applied the hybrid MCDM method AHP and VIKOR in a fuzzy environment for the evaluation of the e-government website. Akincilar and Dagdeviren [50] have proposed a hybrid multi-criteria decision-making model based on the AHP and PROMETHEE in order to evaluate the websites of the hotels. Ecer [51] uses the AHP and COPRAS-G to conduct the evaluation of the quality of websites in the banking industry. Stanujkic et al. [5] provide an approach to the measuring of the website quality in the rural tourism industry 
based on Atanassov's intuitionistic fuzzy sets. Jain et al. [52] uses the TOPSIS method for the evaluation of e-learning websites; also, Jain et al. [53] use weighted distance-based approximation for the selection and ranking of e-learning websites. Kang et al. [54] uses the fuzzy hierarchical TOPSIS based on the ESQUAL model for the evaluation of e-commerce websites. Stanujkic and Karabasevic [55] uses extension of the WASPAS method with intuitionistic fuzzy numbers for the evaluation of websites.

In this manuscript, the application of the WS PLP method introduced by Stanujkic and Zavadskas [27] is proposed. This method represents the improvement of the WS method. The mentioned method is very applicable and easy to use and until now it is successfully applied for the solving of various types of the decisionmaking problems, such as: the ranking of transportation zones [56], the estimation of technologies for the power supply [57], the evaluation of the sustainability of transport noise [58] and performing a decision-making process in a fuzzy environment [59-60]. The WS PLP method is used in the field of human resources management [61-63] and for the estimation of the froth flotation reagents [64]. The WS PLP method could, also, enable the facilitating of the evaluation process in the field of the website quality performed by the customers by utilizing its advantage of incorporating the DM's point of view in a better way.

\section{The WS PLP Approach}

Based on the WS method, proposed by Churchman and Ackoff [32] and MacCrimmon [33], Stanujkic and Zavadskas [27] proposed the WS PLP approach. The normalization procedure introduced by Stanujkic et al. [65] that incorporates the DM`s preferences for preferred performance ratings (ppr) initiated the idea for the forming of new decision-making method. The standpoint of the DM related to the value of criteria is incorporated in every MCDM method in certain degree, but in this case, through the $p p r$ values, the DM`s concretely and exactly express the desired values of the considered criteria. This specified set of $p p r$ values directly affect evaluation of alternatives by transforming them into the group of acceptable alternatives among which the selection should be performed.

In the case of website quality estimation, DMs usually exactly know what features should have the certain website. The $p p r$ values, as a part of the WS PLP method, enable making of an adequate decision that includes expectations and requirements of the DM in greater extent. Exactly this $p p r$ values lead to the similarity of the WS PLP method with the SERVQUAL model because this values represents the expectations of the DM, while the given estimations of the alternatives represent their perceptions. Also, there is a possibility to make a choice between the alternative that better match with the given $p p r$ values and the alternative that has the best overall performance rating. Compensation coefficient 
that is a part of the procedure of the WS PLP method, gives the opportunity to the DM to choose between the mentioned options. Besides, the DM could easily define whether an alternative is better ranked because of only or several criteria that has good ratings and, in that way, the possibility of selection of the alternative along with neglecting of other requirements is avoided.

Evaluation of the quality of website given in this manuscript is performed by using the WS PLP method, whose computational procedure can accurately be presented as follows [27]:

$S_{i}^{\prime}=\sum_{j=1}^{n} w_{j} r_{i j}-\gamma c_{i}$,

where $S_{i}^{\prime}$ denotes the adjusted overall performance rating of the alternative $i$; $S_{i}^{\prime} \in[-1,1], w_{j}$ is the weight of the criterion $j, r_{i j}$ is the normalized performance rating of the alternative $i$ with respect to the criterion $j, n$ is the number of the criteria, $c_{i}$ is the compensation coefficient; $c_{i}>0, \gamma$ is the coefficient; $\gamma=[0,1]$.

The normalized performance ratings in the WS PLP approach should be calculated as follows:

$r_{i j}=\frac{x_{i j}-x_{0 j}}{x_{j}^{+}-x_{j}^{-}}$,

where: $x_{i j}$ denotes performance rating of alternative $i$ in relation to the criterion $j$, $x_{0 j}$ denotes the preferred performance rating of the criterion $j, x_{j}^{+}$and $x_{j}^{-}$denotes the best and the worst ratings of criterion $j$, respectively, and they are calculated as follows:

$$
\begin{aligned}
& x_{j}^{+}=\left\{\begin{array}{l}
\max _{i} x_{i j} \mid j \in \Omega_{\max } \\
\min _{i} x_{i j} \mid j \in \Omega_{\max }
\end{array},\right. \text { and } \\
& x_{j}^{-}=\left\{\begin{array}{l}
\min _{i} x_{i j} \mid j \in \Omega_{\max } \\
\max _{i} x_{i j} \mid j \in \Omega_{\max }
\end{array}\right.
\end{aligned}
$$

The preferred performance rating $x_{0 j}$ of the evaluation criterion $j$ should be set on the basis of the preferences made by the decision maker/respondent. If he/she does not have any preferences in relation to any criterion, such a criterion should be determined as follows:

$$
x_{o j}=\left\{\begin{array}{l}
\max _{i} x_{i j} \mid j \in \Omega_{\max } \\
\min _{i} x_{i j} \mid j \in \Omega_{\min }
\end{array} .\right.
$$


In the proposed approach, the alternatives whose $S_{i}^{\prime}$ is greater than or equal to zero form a set of the most appropriate alternatives, from which one should be selected.

The part $-\gamma c_{i}$ of Eq. (1) can be used to reduce the number of the alternatives or to fine tune the values of $S_{i}^{\prime}$ in the set of the most appropriate alternatives. However, its use is not mandatory.

The meaning and the usage of $-\gamma c_{i}$ part of Eq. (1) are explained in detail in Stanujkic and Zavadskas [27].

\section{The Framework for Evaluating the Website Quality}

Different authors have identified different phases in the multiple criteria evaluation process. Many of them have highlighted some as those important for the further consideration of the proposed approach, such as [66-68]:

- the selection of relevant evaluation criteria,

- the determination of the criteria weights, and

- the aggregation and selection phase.

In the following text every phase is further elaborated.

\subsection{The Selection of Relevant Evaluation Criteria}

The choice of the appropriate set of the evaluation selection criteria is very important for the successful solving of each MCDM problem. The evaluation of the website quality performed by Kaya [69] is based on the four groups of criteria which are as follows: information quality, service quality, system quality and vendor quality. Every of the mentioned criteria group consists of two additional criteria that better explain the considered aspect of website quality. Kaya and Kahraman [70] in their manuscript based the evaluation of the e-banking websites on the two dimensions: (1) customer service quality criteria that involve: product quality, reliability, responsiveness, competence and access; and (2) online systems quality criteria that involves: information content, ease of use and security. Akincilar and Dagdeviren [50] evaluated the quality of the hotel websites by using the following criteria that is further elaborated in the certain number of subcriteria: customer oriented, technology oriented, marketing oriented, security oriented and other factors.

The common denominator for all previous approaches is that the evaluation process is based on the greater number of criteria and sub-criteria. Using a larger 
number of criteria usually leads to the formation of more precise models, on the one hand, whereas on the other, a larger number of criteria can, however, be less desirable if some data should be collected through a survey. In contrast to the said, a smaller number of criteria can be much more efficient when some data should be collected through a survey, on the one hand, whereas on the other, the usage of more complex criteria is required sometimes, which can also lead to the forming of less accurate models. There is also a set of rules that a set of evaluation criteria should satisfy, such as: completeness, the operational ability, decomposability, non-redundancy and the minimum size [71].

Therefore, in this approach a proven set of evaluation criteria, which has been adopted from the Webby Awards ${ }^{1}$, is proposed for evaluating the quality of the website:

- Content $(\boldsymbol{C})$ - The content is the information provided on the website. It is not just the text, but also the music, the sound, the animation or a video anything that communicates the body of knowledge of the website.

- Structure and Navigation $(S)$ - The structure and navigation refer to the framework of the website, the organization of the content, the prioritization of the information and the method in which the website is navigated by the visitor. Websites with the good structure and navigation are consistent, intuitive and transparent.

- Visual Design ( $\boldsymbol{V})$ - Visual design is the appearance of the website. It is more than just a nicely designed homepage and it does not have to be the cutting edge or anything trendy. A good visual design is of a high quality, appropriate and relevant for the audience and the message it supports. It communicates a visual experience and may even take your breath away.

- Functionality $(\boldsymbol{F})$ - Functionality is the use of technology on the website. Good functionality means that the website works well. It loads quickly, has live links and the different kinds of the new technology applied to it are functional and relevant for the intended audience.

- Innovation (I) - Innovation is the idea that is completely new and contributes to the better functioning or visual design of some website.

- Overall Experience $(\boldsymbol{O})$ - Demonstrating the fact that websites are frequently more or less than the sum of their parts, the overall experience encompasses the content, visual design, functionality, interactivity and the structure and navigation, on the one hand, also including the intangibles that make the visitor stay on it or leave it, on the other.

In this case, the criterion Innovation is omitted from the evaluation procedure. The reason for excluding of mentioned criterion from the assessment of the websites quality is twofold. Firstly, examination of the research studies shows that evaluation of the quality of websites mainly relies on the criteria that roughly could be categorized as follows: content, navigation, visual appeal, multimedia

\footnotetext{
${ }^{1}$ http://webbyawards.com/judging-criteria/
} 
and ease of use [72-74]. Secondly, the Innovation criterion is omitted from the assessment because its meaning could be confusing to the respondents. Besides, the Overall Experience criterion is used for checking the reliability of the collected data and the evaluation results.

The given set of criteria is reliable because it is proved to be useful for the estimation of the website quality. Besides, its application facilitates decisionmaking process, which is liberated from the large number of criteria that complicates the procedure.

\subsection{The Determination of Criteria Weights}

The determination of the significance of criteria is of great importance in multiple criteria evaluation models, which is why a number of methods for their determination have been proposed, such as: the Analytic Hierarchy Process (AHP), developed by Saaty [35-36], the Step-wise Weight Assessment Ratio Analysis (SWARA) technique, developed by Kersuliene et al. [44], and the pivot pairwise relative criteria importance assessment method for determining the weights of criteria (PIPRECIA) [75].

In this approach, the preferred ratings obtained from the respondents are used for the determining of the significance of the evaluation criteria, i.e. the weights of the criteria, as follows:

$w_{j}=\frac{x_{0 j}}{\sum_{l=1}^{n} x_{0 l}}$,

where $x_{0 j}$ denotes the preferred performance rating of the criterion $j$ and $x_{0 l}$ denotes the preferred performance ratings.

\subsection{The Aggregation and Selection Phase}

In this approach, the WS PLP approach is chosen for aggregating the ratings collected during the survey for each one of the respondents separately. This means that the $K$ ranking orders will be formed in the case of a survey that includes $K$ respondents.

There are several ways for the evaluation of the alternatives. The first approach is the theory of dominance [42] based on the number of the occurrences of some alternative in the first position. The number of the occurrences in the other positions, the second, and the third and so on, can also be significant for a more precise evaluation. 
The Weighted Averaging (WA) operator, proposed by Harsanyi [76], can be used as an alternative way for the transformation of the $K$ ranking list into the resulting ranking list.

\section{A Case Study}

In order to verify the proposed framework, a limited research related to the quality of the websites of the three telecommunication companies in Serbia was conducted.

The e-mail survey was carried out, and e-mails were sent to more than 80 preselected email addresses. The positive feedback response was obtained from 51 respondents, out of which 45 surveys were selected as properly completed. Respondents appraised before mentioned websites against the given set of criteria using the marks 1 to 5 ( 1 as the worst and 5 as the best mark).

In order to demonstrate not only the efficiency, but also the simplicity of the use of the proposed framework, the evaluation performed on the basis of the five randomly selected respondents is presented below.

The ratings obtained from the selected respondents are shown in Tables 1 to 5 .

Table 1

The ratings and the preferred ratings obtained from the first of the five selected respondents

\begin{tabular}{|c|c|c|c|c|c|c|}
\hline Criteria & $C_{1}$ & $C_{2}$ & $C_{3}$ & $C_{4}$ & $C_{5}$ & \multirow{2}{*}{ Overall } \\
\hline \multicolumn{1}{|c|}{$p p r$} & 3 & 4 & 5 & 2 & 1 & 4 \\
\hline$A_{1}$ & 2 & 4 & 5 & 3 & 2 & 4 \\
\hline$A_{2}$ & 2 & 3 & 3 & 4 & 2 & 1 \\
\hline$A_{3}$ & 3 & 4 & 5 & 2 & 1 & 4 \\
\hline
\end{tabular}

Table 2

The ratings and the preferred ratings obtained from the second of the five selected respondents

\begin{tabular}{|c|c|c|c|c|c|c|}
\hline Criteria & $C_{1}$ & $C_{2}$ & $C_{3}$ & $C_{4}$ & $C_{5}$ & \multirow{2}{*}{ Overall } \\
\hline \multicolumn{1}{|c|}{$p p r$} & 3 & 5 & 5 & 4 & 1 & \\
\hline$A_{1}$ & 2 & 4 & 5 & 3 & 2 & 4 \\
\hline$A_{2}$ & 2 & 3 & 4 & 2 & 2 & 2 \\
\hline$A_{3}$ & 3 & 4 & 5 & 2 & 1 & 4 \\
\hline
\end{tabular}

Table 3

The ratings and the preferred ratings obtained from the third of the five selected respondents

\begin{tabular}{|c|c|c|c|c|c|c|}
\hline Criteria & $C_{1}$ & $C_{2}$ & $C_{3}$ & $C_{4}$ & $C_{5}$ & \multirow{2}{*}{ Overall } \\
\hline \multicolumn{1}{|c|}{$p p r$} & 3 & 4 & 5 & 2 & 1 & 2 \\
\hline$A_{1}$ & 2 & 4 & 5 & 3 & 2 & 1 \\
\hline$A_{2}$ & 2 & 3 & 3 & 4 & 2 & 4 \\
\hline$A_{3}$ & 3 & 4 & 5 & 2 & 1 & 4 \\
\hline
\end{tabular}


Table 4

The ratings and the preferred ratings obtained from the fourth of the five selected respondents

\begin{tabular}{|c|c|c|c|c|c|c|}
\hline Criteria & $C_{1}$ & $C_{2}$ & $C_{3}$ & $C_{4}$ & $C_{5}$ & \multirow{2}{*}{ Overall } \\
\hline \multicolumn{1}{|c|}{$p p r$} & 3 & 4 & 3 & 3 & 1 & \\
\hline$A_{1}$ & 2 & 4 & 5 & 3 & 2 & 3 \\
\hline$A_{2}$ & 2 & 3 & 3 & 4 & 2 & 1 \\
\hline$A_{3}$ & 3 & 4 & 1 & 4 & 1 & 2 \\
\hline
\end{tabular}

Table 5

The ratings and the preferred ratings obtained from the fifth of the five selected respondents

\begin{tabular}{|c|c|c|c|c|c|c|}
\hline Criteria & $C_{1}$ & $C_{2}$ & $C_{3}$ & $C_{4}$ & $C_{5}$ & \multirow{2}{*}{ Overall } \\
\hline \multicolumn{1}{|c|}{$p p r$} & 3 & 4 & 5 & 2 & 1 & 4 \\
\hline$A_{1}$ & 2 & 4 & 5 & 3 & 2 & 4 \\
\hline$A_{2}$ & 2 & 3 & 3 & 4 & 2 & 1 \\
\hline$A_{3}$ & 3 & 4 & 5 & 2 & 1 & 3 \\
\hline
\end{tabular}

The normalized ratings and the weights of the criteria obtained on the basis of the ratings and the preferences of the first respondent by using Eq. (2) and Eq. (6) are shown in Table 6.

Table 6

The normalized ratings and the weighting of the criteria obtained on the basis of the ratings and the preferences of the first of the five selected respondents

\begin{tabular}{|c|c|c|c|c|c|}
\hline Criteria & $C_{1}$ & $C_{2}$ & $C_{3}$ & $C_{4}$ & $C_{5}$ \\
\hline$w_{j}$ & 0.20 & 0.27 & 0.33 & 0.13 & 0.07 \\
\hline$A_{1}$ & -1 & 0 & 0 & 1 & 1 \\
\hline$A_{2}$ & -1 & -1 & -2 & 2 & 1 \\
\hline$A_{3}$ & 0 & 0 & 0 & 0 & 0 \\
\hline
\end{tabular}

The weighted normalized ratings and the overall ratings obtained by using Eq. (1), as well as the ranking order obtained on the responses of the first respondent are accounted for in Table 7 .

Table 7

The computational details obtained on the basis of the responses received from the first of the five selected respondents

\begin{tabular}{|c|c|c|c|c|c|c|c|}
\hline Criteria & $C_{1}$ & $C_{2}$ & $C_{3}$ & $C_{4}$ & $C_{5}$ & $S_{i}$ & Rank \\
\hline$A_{1}$ & 0.00 & 0.00 & 0.00 & 0.07 & 0.07 & 0.13 & 1 \\
\hline$A_{2}$ & -0.20 & -0.27 & -0.33 & 0.13 & 0.07 & -0.60 & 3 \\
\hline$A_{3}$ & 0.00 & 0.00 & 0.00 & 0.00 & 0.00 & 0.00 & 2 \\
\hline
\end{tabular}

According to Table 7, the website of the telecommunication company labelled as $A_{1}$ is the best-ranked and the website of the company labelled as $A_{3}$ is the second best-placed.

The Overall parameter applied in the conducted survey is used for the purpose of determining the consistency of the responses obtained through the survey. 
The results of the ranking obtained on the basis of the responses received from the first of the selected respondents are given in Table 8 .

Table 8

The ranking of the websites on the basis of the Overall parameter obtained from the first of the five selected respondents

\begin{tabular}{|c|c|c|}
\hline Alternatives & Overall & Rank \\
\hline$A_{1}$ & 4 & 1 \\
\hline$A_{2}$ & 1 & 3 \\
\hline$A_{3}$ & 4 & 1 \\
\hline
\end{tabular}

According to Tables 7 and 8, the ranking order obtained on the basis of the five evaluation criteria and the ranking order obtained on the basis of the Overall parameter are similar to one another, which confirms the consistency of the responses received from the first of the selected respondents.

The ranking orders of the considered websites obtained from the responses given by the five selected respondents are shown in Table 9.

Table 9

The ranking orders obtained on the basis of the responses received from the five selected respondents

\begin{tabular}{|c|c|c|c|c|c|c|c|}
\hline Alternatives & $D M_{1}$ & $D M_{2}$ & $D M_{3}$ & $D M_{4}$ & $D M_{5}$ & I & Rank \\
\hline$A_{1}$ & 1 & 1 & 2 & 2 & 1 & 3 & 1 \\
\hline$A_{2}$ & 3 & 2 & 3 & 3 & 3 & 0 & 3 \\
\hline$A_{3}$ & 2 & 3 & 1 & 1 & 2 & 2 & 2 \\
\hline
\end{tabular}

According to Table 9, the website $A_{1}$ is the most appropriate, based on the responses obtained from the five selected respondents because it has the greatest number of appearances in the first position.

The website $A_{3}$ is the runner up, with three appearances in the first position and two appearances in the second position, which is indicative of the fact that this particular website could surpass the website $A_{1}$, based on certain adjustments to that website.

The ranking order obtained on the basis of appearance in the first position is also confirmed by using the WA operator, as Table 10 shows.

Table 10

The ranking of the websites on the basis of the WA operator and the ratings obtained from the five selected respondents

\begin{tabular}{|c|c|c|}
\hline Alternatives & $S_{i}$ & Rank \\
\hline$A_{1}$ & -0.14 & 1 \\
\hline$A_{2}$ & -0.57 & 3 \\
\hline$A_{3}$ & -0.27 & 2 \\
\hline
\end{tabular}

The value -0.14 of the overall rating of the website $A_{1}$ indicates the fact that its overall quality is below the respondents' expectations. By analyzing their 
responses, the website $A_{1}$ was found to mainly fail in relation the Content criterion, as is shown in Table 11.

\section{Table 11}

The weighted normalized ratings of the website $A_{1}$, obtained from the selected respondents

\begin{tabular}{|c|c|c|c|c|c|}
\hline Criteria & $C_{1}$ & $C_{2}$ & $C_{3}$ & $C_{4}$ & $C_{5}$ \\
\hline$D M_{1}$ & 0.00 & 0.00 & 0.00 & 0.07 & 0.07 \\
\hline$D M_{2}$ & -0.17 & -0.28 & 0.00 & -0.22 & 0.02 \\
\hline$D M_{3}$ & -0.20 & 0.00 & 0.00 & 0.07 & 0.07 \\
\hline$D M_{4}$ & -0.21 & 0.00 & 0.11 & 0.00 & 0.07 \\
\hline$D M_{5}$ & -0.20 & 0.00 & 0.00 & 0.07 & 0.07 \\
\hline
\end{tabular}

The ranking orders of the considered websites obtained on the basis of the responses received from all the surveyed respondents are accounted for in Table 12 .

Table 12

The ranking orders obtained on the basis of all the respondents' responses

\begin{tabular}{|c|c|c|c|}
\hline Alternatives & I & Rank & $\%$ \\
\hline$A_{1}$ & 30 & 1 & $67 \%$ \\
\hline$A_{2}$ & 6 & 3 & $13 \%$ \\
\hline$A_{3}$ & 9 & 2 & $20 \%$ \\
\hline
\end{tabular}

According to Table 12, the website $A_{1}$ is still the first-placed, with 30 appearances in the first position, which is $67 \%$ if expressed in percentage.

The dominance of the website $A_{1}$ could also be confirmed by using the WA operator, as well as by the ranking based on the Overall parameter, as is shown in Table 13 and Table 14.

Table 13

The ranking orders of the websites on the basis of the WA operator

\begin{tabular}{|c|c|c|}
\hline Alternatives & $S_{i}$ & Rank \\
\hline$A_{1}$ & -0.35 & 1 \\
\hline$A_{2}$ & -0.72 & 3 \\
\hline$A_{3}$ & -0.64 & 2 \\
\hline
\end{tabular}

Table 14

The ranking orders obtained on the basis of the Overall parameter

\begin{tabular}{|c|c|c|c|}
\hline Alternatives & I & Rank & $\%$ \\
\hline$A_{1}$ & 10 & $48 \%$ & 1 \\
\hline$A_{2}$ & 5 & $24 \%$ & 3 \\
\hline$A_{3}$ & 6 & $29 \%$ & 2 \\
\hline
\end{tabular}

Additionally, in order to verify the reliability of the proposed approach, sensitivity analysis was conducted with the comparison of the ranking results of the WS PLP method with 5 other well-known MCDM methods (TOPSIS, VIKOR, ARAS, MULTIMOORA and WASPAS). The obtained results are shown in Figure 1. 


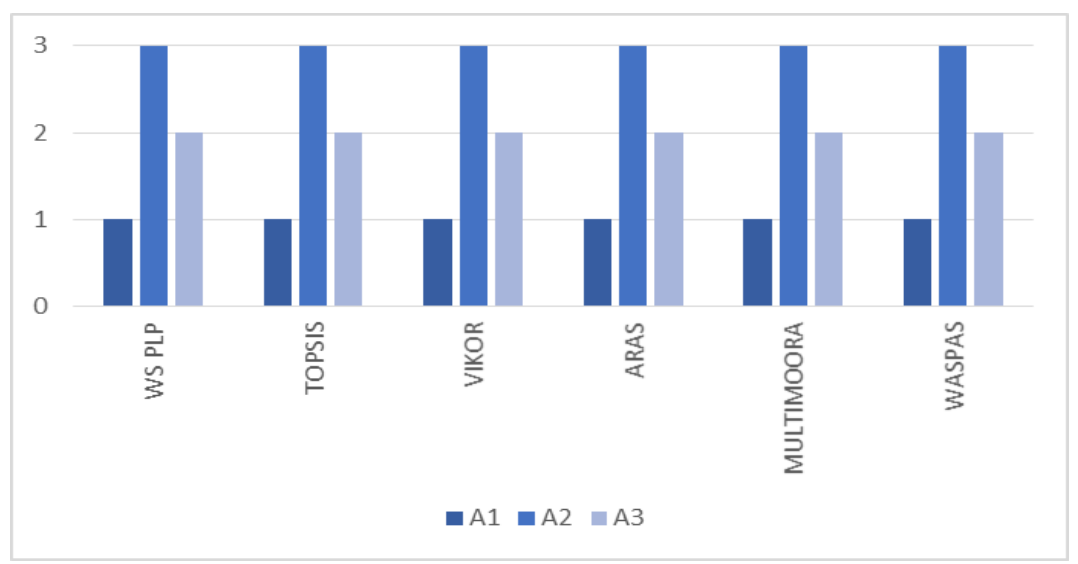

Figure 1

Results of sensitivity analysis in comparison of ranks with other MCDM methods

The comparison results of the conducted sensitivity analysis indicate that proposed approach have the same ranking results as well as other methods, which confirms that the proposed approach is reliable and adequate when it comes to website evaluation.

\section{Conclusion}

A new approach to the evaluation and ranking of websites from the viewpoint of their respective visitors is the subject matter of consideration in this manuscript. The main goal of the paper is proposing the WS PLP method as a suitable technique for the website quality evaluation that could be used by the customers or the companies. The capability of the WS PLP method application in the mentioned case is dual. This method could help customers to select the website according to their needs, but also, companies could evaluate the quality of their websites, and determine its position in relation to the main competitors as well providing the information regarding the main aspects that should be improved.

The approach proposed herein also has significant similarities to the proven approaches of the determination of customers' satisfaction, such as SERVQUAL or models similar to that one. The main similarity to the SERVQUAL model is related to the fact that the proposed approach also uses gaps between expectations and perceptions. By introducing the $p p r$ values the DM's could better to express their expectations and perform the comparisons with the given performances of the alternatives. Also, the DM is in the position to choose whether he/she wants to give priority to the alternative that is better matching with his/her expectations or to the one that is the best of all.

The before mentioned authors such as Kaya [69], Kaya and Kahraman [70] and Akincilar and Dagdeviren [50] have based their evaluation of the website quality on the greater number of criteria and sub-criteria that leads to the more complex 
procedure and that is very complicated for the application in the practice by ordinary users. Approach proposed in this paper, which is based on the significantly smaller number of criteria, enables forming of the simpler questionnaires that could be more appropriate when preferences and ratings are collected through conducting surveys with ordinary respondents, i.e. those unprepared in advice for surveying.

The principal disadvantage of this approach is the use of the crisp numbers. Despite that, the proposed approach proved to be useful when it comes to solving problems of websites evaluation.

In the end, the usability of the proposed approach is tested and verified in the case study on the evaluation of the websites of the telecommunication companies. Also, additional verification of the proposed approach is demonstrated in the conducted sensitivity analysis. The obtained result has confirmed that the proposed approach is proven to be reliable and adequate for solving problems of website quality evaluation.

\section{References}

[1] Taylor, M. and Kent, M. L., (2004) Congressional web sites and their potential for public dialogue. Atlantic Journal of Communication, 12(2), pp. 59-76

[2] Cebi, S., (2013) Determining importance degrees of website design parameters based on interactions and types of websites. Decision Support Systems, 54(2), pp. 1030-1043

[3] Ibrahim, M., (2015) Evaluating hotel websites as a marketing communication channel A dialogic perspective. Information Development, 32(3), pp. 1-10

[4] Lee, Y. and Kozar, K. A., (2006) Investigating the effect of website quality on e-business success: An analytic hierarchy process (AHP) approach. Decision support systems, 42(3), pp. 1383-1401

[5] Stanujkic, D. Kazimieras Zavadskas, E. and Tamošaitienè, J., (2015) An approach to measuring website quality in the rural tourism industry based on Atanassov intuitionistic fuzzy sets. Ekonomie a Management, 18(4), pp. 184-199

[6] Al-Manasra, E. Khair, M. Zaid, S. A. and TaherQutaishat, F., (2013) Investigating the Impact of Website Quality on Consumers' Satisfaction in Jordanian Telecommunication Sector. Arab Economic and Business Journal, 8(1), pp. 31-37

[7] Bai, B. Law, R. and Wen, I., (2008) The impact of website quality on customer satisfaction and purchase intentions: Evidence from Chinese online visitors. International Journal of Hospitality Management, 27(3), pp. 391-402 
[8] Lin, H. F. (2007) The impact of website quality dimensions on customer satisfaction in the B2C e-commerce context. Total Quality Management and Business Excellence, 18(4), pp. 363-378

[9] Kim, S., and Stoel, L., (2004) Apparel retailers: website quality dimensions and satisfaction. Journal of Retailing and Consumer Services, 11(2), pp, 109-117

[10] Parasuraman, A. Zeithaml, V. A. and Berry, L. L., (1985) A conceptual model of service quality and its implications for future research. Journal of Marketing, 49, pp. 41-50

[11] Barnes, S. J. and Vidgen, R., (2001) An evaluation of cyber-bookshops: the WebQual method. International Journal of Electronic Commerce, 6(1), pp. $11-30$

[12] Barnes, S. and Vidgen, R., (2000) WebQual: an exploration of website quality. ECIS 2000 Proceedings, 74

[13] Parasuraman, A. Zeithaml, V. A. and Malhotra, A., (2005) ES-QUAL a multiple-item scale for assessing electronic service quality. Journal of service research, 7(3), pp. 213-233

[14] Loiacono, E. T. Watson, R. T. and Goodhue, D. L., (2002) WebQual: A measure of website quality. Marketing theory and applications, 13(3), pp. $432-438$

[15] Barnes, S. J. and Vidgen, R. T., (2003) Assessing the quality of a crossnational e-government Web site: a study of the forum on strategic management knowledge exchange. In System Sciences, 2003, Proceedings of the $36^{\text {th }}$ Annual Hawaii International Conference on (pp. 10-pp) IEEE

[16] Barnes, S. J. and Vidgen, R., (2003) Measuring Website Quality Improvements: A Case Study of the Forum on Strategic Management Knowledge Exchange. Industrial Management and Data System, 103(5), pp. 297-309

[17] Shchiglik, C. and Barnes, S. J., (2004) Evaluating website quality in the airline industry. Journal of Computer Information Systems, 44(3), pp. 17-25

[18] Park, Y. A. Gretzel, U. and Sirakaya-Turk, E., (2007) Measuring web site quality for online travel agencies. Journal of Travel \& Tourism Marketing, 23(1), pp. 15-30

[19] Park, H. and Baek, S., (2007) Measuring service quality of online bookstores with WebQual. In International Conference on HumanComputer Interaction, Springer, Berlin Heidelberg, pp. 95-103

[20] Keeney, R. and Raiffa, H., (1976) Decision with multiple objective: Preference and value tradeoffs. Wiley, New York 
[21] Beynon, M. J., (2006) The role of the DS/AHP in identifying inter-group alliances and majority rule within group decision making. Group decision and negotiation, 15(1), pp. 21-42

[22] Korhonen, P., (2005) Interactive methods. In Multiple criteria decision analysis: state of the art surveys. Springer, New York

[23] Karabasevic, D., Popovic, G., Stanujkic, D., Maksimovic, M. and Sava, C., (2019) An approach for hotel type selection based on the single-valued intuitionistic fuzzy numbers. International Review (1-2), pp. 9-16

[24] Nunić, Z., (2018) Evaluation and selection of Manufacturer PVC carpentry using FUCOM-MABAC model. Operational Research in Engineering Sciences: Theory and Applications, 1(1), pp. 13-28

[25] Pamučar, D., Lukovac, V., Božanić, D. and Komazec, N., (2018) Multicriteria FUCOM-MAIRCA model for the evaluation of level crossings: case study in the Republic of Serbia. Operational Research in Engineering Sciences: Theory and Applications, 1(1), pp. 108-129

[26] Vesković, S., Stević, Ž., Stojić, G., Vasiljević, M., and Milinković, S., (2018) Evaluation of the railway management model by using a new integrated model DELPHI-SWARA-MABAC. Decision Making: Applications in Management and Engineering, 1(2), pp. 34-50

[27] Stanujkic, D. and Zavadskas, E. K., (2015) A modified weighted sum method based on the decision-maker's preferred levels of performances. Studies in Informatics and Control, 24(4), pp. 61-470

[28] Jones, C. and Kim, S., (2010) Influences of retail brand trust, off-line patronage, clothing involvement and website quality on online apparel shopping intention. International Journal of Consumer Studies, 34(6), pp. 627-637

[29] Wang, L. Law, R. Guillet, B. D. Hung, K. and Fong, D. K. C., (2015) Impact of hotel website quality on online booking intentions: eTrust as a mediator. International Journal of Hospitality Management, 47, pp. 108115

[30] Yang, K. Li, X. Kim, H. and Kim, Y. H., (2015) Social shopping website quality attributes increasing consumer participation, positive eWOM, and co-shopping: The reciprocating role of participation. Journal of Retailing and Consumer Services, 24, pp. 1-9

[31] Calero, C. Ruiz, J. and Piattini, M., (2005) Classifying Web Metrics Using the Web Quality Model. Online Information Review, 29(3), pp. 227-248

[32] Churchman, C. W. and Ackoff, R. L., (1954) An approximate measure of value. Journal of the Operations Research Society of America, 2(2), pp. $172-187$ 
[33] MacCrimon, K. R., (1968) Decision Marking Among Multiple-Attribute Alternatives: A Survey and Consolidated Approach. RAND memorandum, RM-4823-ARPA

[34] Roy, B., (1968) Classement et choix en présence de points de vue multiples. Revue française d'automatique, d'informatique et de recherche opérationnelle. Recherche opérationnelle, 2(1), pp. 57-75

[35] Saaty, T. L., (1977) A scaling method for priorities in hierarchical structures. Journal of mathematical psychology, 15(3), pp. 234-281

[36] Saaty, T. L., (1980) The Analytic Hierarchy Process. McGraw Hill Company, New York

[37] Hwang, C. L. and Yoon, K., (1981) Multiple Attribute Decision Making Methods and Applications. Springer-Verlag, Heidelberg

[38] Brans, J. P. and Vincke, P., (1985) Note-A Preference Ranking Organisation Method: (The PROMETHEE Method for Multiple Criteria Decision-Making). Management science, 31(6), pp. 647-656

[39] Zavadskas, E. K. Kaklauskas, A. and Sarka V., (1994) The New Method of Multicriteria Complex Proportional Assessment of Projects. Technological and Economic Development of Economy, 1(3), pp. 131-139

[40] Opricovic, S., (1998) Multicriteria optimization of civil engineering systems. Faculty of Civil Engineering, Belgrade

[41] Grigoroudis, E. and Siskos, Y., (2002) Preference disaggregation for measuring and analysing customer satisfaction: The MUSA method. European Journal of Operational Research, 143(1), pp. 148-170

[42] Brauers, W. K. M., and Zavadskas, E. K., (2010) Project management by MULTIMOORA as an instrument for transition economies. Technological and Economic Development of Economy, 16(1), pp. 5-24

[43] Zavadskas, E. K. and Turskis, Z., (2010) A New Additive Ratio Assessment (ARAS) Method in Multicriteria Decision-Making. Technological and Economic Development of Economy, 16(2), pp. 159-172

[44] Kersuliene, V. Zavadskas, E. K. and Turskis, Z., (2010) Selection of rational dispute resolution method by applying new step-wise weight assessment ratio analysis (SWARA). Journal of Business Economics and Management, 11(2), pp. 243-258

[45] Ginevičius, R., (2011) A new determining method for the criteria weights in multicriteria evaluation. International Journal of Information Technology \& Decision Making, 10(6), pp. 1067-1095

[46] Zavadskas, E. K. Turskis, Z. Antucheviciene, J. and Zakarevicius, A., (2012) Optimization of Weighted Aggregated Sum Product Assessment. Elektronika ir elektrotechnika, 122(6), pp. 3-6 
[47] Krylovas, A. Zavadskas, E. K. Kosareva, N. and Dadelo, S., (2014) New KEMIRA method for determining criteria priority and weights in solving MCDM problem. International Journal of Information Technology \& Decision Making, 13(6), pp. 1119-1133

[48] Ghorabaee, M. K. Zavadskas, E. K. Olfat, L. and Turskis, Z., (2015) MultiCriteria Inventory Classification Using a New Method of Evaluation Based on Distance from Average Solution (EDAS). Informatica, 26(3), pp. 435451

[49] Burmaoglu, S. and Kazancoglu, Y., (2012) E-government website evaluation with hybrid MCDM method in fuzzy environment. International Journal of Applied Decision Sciences, 5(2), pp. 163-181

[50] Akincilar, A. and Dagdeviren, M., (2014) A hybrid multi-criteria decision making model to evaluate hotel websites. International Journal of Hospitality Management, 36, pp. 263-271

[51] Ecer, F., (2014) A hybrid banking websites quality evaluation model using AHP and COPRAS-G: A Turkey case. Technological and Economic Development of Economy, 20(4), pp. 758-782

[52] Jain, D. Garg, R. and Bansal, A., (2015) A Parameterized Selection and Evaluation of E-Learning Websites Using TOPSIS Method. International Journal of Research \& Development, 22(3), pp. 12-26

[53] Jain, D. Garg, R. Bansal, A. and Saini, K. K., (2016) Selection and ranking of E-learning websites using weighted distance-based approximation. Journal of Computers in Education, 3(2) pp. 193-207

[54] Kang, D. Jang, W. and Park, Y., (2016) Evaluation of e-commerce websites using fuzzy hierarchical TOPSIS based on ES-QUAL. Applied Soft Computing, 42, pp. 53-65

[55] Stanujkić, D. and Karabašević, D., (2018) An extension of the WASPAS method for decision-making problems with intuitionistic fuzzy numbers: a case of website evaluation. Operational Research in Engineering Sciences: Theory and Applications, 1(1), pp. 29-39

[56] Jakimavičius, M. Burinskiene, M., (2009) A GIS and multi-criteria based analysis and ranking of transportation zones of Vilnius city. Technological and Economic Development of Economy 15(1), pp. 39-48

[57] Shakouri, H. Nabaee, M. and Aliakbarisani, S., (2014) A quantitative discussion on the assessment of power supply technologies: DEA (data envelopment analysis) and SAW (simple additive weighting) as complementary methods for the "Grammar". Energy, 64, pp. 640-647

[58] Oltean-Dumbrava, C. Watts, G. Miah, A., (2016) Towards a more sustainable surface transport infrastructure: A case study of applying multi criteria analysis techniques to assess the sustainability of transport noise reducing devices. Journal of Cleaner Production, 112, pp. 2922-2934 
[59] Chen, T. Y., (2012) Comparative analysis of SAW and TOPSIS based on interval-valued fuzzy sets: discussions on score functions and weight constraints. Expert Systems with Applications, 39(2), pp. 1848-1861

[60] Wang, P. Zhu, Z. and Wang, Y., (2016) A novel hybrid MCDM model combining the SAW, TOPSIS and GRA methods based on experimental design. Information Sciences, 345, pp. 27-45

[61] Karabašević, D. Stanujkić, D. Đorđević, B. and Stanujkić, A., (2018) The weighted sum preferred levels of performances approach to solving problems in human resources management. Serbian Journal of Management, 13(1), pp. 145-156

[62] Stanujkic, D. Karabasevic, D. and Zavadskas, E. K., (2017) A New Approach For Selecting Alternatives Based On The Adapted Weighted Sum And The Swara Methods: A Case Of Personnel Selection. Economic Computation \& Economic Cybernetics Studies \& Research, 51(3) pp. 39-56

[63] Vujić, D. Stanujkić, D. Urošević, S. and Karabašević, D., (2016) An approach to leader selection in the mining industry based on the use of weighted sum preferred levels of the performances method. Mining and Metallurgy Engineering Bor, 4, pp. 53-62

[64] Stanujkić, D. Milanović, D. Magdalinović, S. and Jovanović, I., (2017) An approach to the evaluation of froth flotation reagents based on the use of the SWARA and WS-PLP methods. Mining and Metallurgy Engineering Bor, 3-4, pp. 103-110

[65] Stanujkic, D. Magdalinovic, N. and Jovanovic, R., (2013) A multi-attribute decision making model based on distance from decision maker's preferences, Informatica 24(1), pp. 103-118

[66] Čupić, M. Tummala, R. and Suknović, M., (2003) Decision-makingFormal approach. Faculty of Organizational Sciences, Belgrade (In Serbian)

[67] Schoenfeld, A. H., (2010) How we think: A theory of goal-oriented decision making and its educational applications. Routledge, New York

[68] Stanujkić, D. Đorđević, B. and Đorđević, M., (2013) Comparative analysis of some prominent MCDM methods: A case of ranking Serbian banks. Serbian Journal of Management, 8(2), pp. 213-241

[69] Kaya, T., (2010) Multi-attribute evaluation of website quality in E-business using an integrated fuzzy AHPTOPSIS methodology. International Journal of Computational Intelligence Systems, 3(3), pp. 301-314

[70] Kaya, T. and Kahraman, C., (2011) A fuzzy approach to e-banking website quality assessment based on an integrated AHP-ELECTRE method. Technological and Economic Development of Economy, 17(2), pp. 313-334 
[71] Keeney, R. L. and Gregory, R. S., (2005) Selecting attributes to measure the achievement of objectives. Operations Research, 53(1), pp. 1-11

[72] Moustakis, V., Litos, C., Dalivigas, A. and Tsironis, L., (2004) Website Quality Assessment Criteria. ICIQ, pp. 59-73

[73] Kincl, T. and Štrach, P., (2012) Measuring website quality: asymmetric effect of user satisfaction. Behaviour \& Information Technology, 31(7), pp. 647-657

[74] Rocha, Á., (2012) Framework for a global quality evaluation of a website. Online Information Review, 36(3), pp. 374-382

[75] Stanujkic, D. Zavadskas, E. K. Karabasevic, D. Smarandache, F. and Turskis, Z., (2017) The use of the pivot pairwise relative criteria importance assessment method for determining the weights of criteria. Romanian Journal for Economic Forecasting, 20(4), pp. 116-133

[76] Harsanyi, J. C., (1995) Cardinal welfare, individualistic ethics, and interpersonal comparisons of utility. Journal of Political Economy, 63(4), pp. 309-321 